\title{
Analysis of Employee Performance on Education Department of Makassar
}

\author{
Mochtar Luthfi Masiming \\ Universitas Islam Makassar, Indonesia
}

\begin{abstract}
The aims of this research is to analyze (1). The description the officers' performance at Departement of Makassar, (2). Factors determinant that influence the officers' performance at Department of Education of Makassar. The population of research is the whole officers' at Department of Education of Makassar. The research respondents were 68 officers' taken by using Disproportionate Stratified Random Sampling. The hypothetical influence between variable tested and multiple regression analysis. Data processing used software SPSS 15.0 version. The result of research shows that variable of working motivation, income, education, age, working period, officers' attitude and working environment influence significantly the officers' working variable simultaneously either partially. The result of the research as well determines the strong relationship between working motivation, income, education, age, working, period, officers' attitude and working environment with the officers' education at department of education of Makassar.
\end{abstract}

\section{Introduction}

Ideally Public administration is truly able to use the expertise and skills in the areas of policy, organization, management, applying the principles of ethics, and is able to recognize and adapt to the dynamics of the environment, as well as delivering tangible results and can be accounted for in terms of performance (Keban, 2004). According to Keban (2004) dimensions of performance is an important element of the public adimnistrasi. It is a vital part of the effectiveness of public services.

Public service from government officials, especially in the city of Makassar today, many units which weakness so hasnt met the excellent service expected society. It is characterized by still be found or found various society complaints is conveyed through mass media who inflicts image less good against government officials. Considering the main function of government serve people is then the government need to improve service quality.

The low level of performance of employees in carrying out the public service becomes a problem which must be resolved in order for the employees of Makassar Education Department can carry out their duties properly in providing excellent service to the community. It is caused by the rapid development and progress in education department. The focus activity, both the quantity and quality of the facilities and infrastructure of education ranging from pre-school education, primary education, out-of-school education, secondary education, to higher education.

Based on empirical observations, interviews, and supported by information from various parties, the issues relating to low employee performance in carrying out public services can be identified;

1. Lack of leader's attention and motivation

2. The lack of facilities of work

3. The weakness income distribution additional allowance

4. Government regulation about extension pension age for employees were excellent for pimpinan would undermine systems develop the career staff according to work performance.

5. The low chance to implement of public service activities.

6. Attitude employees in providing services are lacking.

7. A work environment lacking support

Based on description, mentioned above the question research is whether the work motivation, employee income, education, age, length of service, attitude of employees, and the work environment affects employee performance?

\section{Theoritical framework}

\section{Perspective of Public administration theory}

Basically, the public administration is not a goal but a means to achieve a goal. Tjokroamidjoyo (1985) explained that the admnistration district of the public as a means to meet the criteria of efficiency, effectiveness and rationality in the achievement of the purposes for which it is expected that operational engineering tasks in 
the framework of the implementation of basic tasks are also expected to be efficient, effective, and rational, and should not be problematic technical tasks which do not smoothly solved, there was wastage of resources and objectives not achieved as expected

\section{Employee's Performance}

Vroom (1964) explained that the performance affected by the interaction of ability and motivation. Blumberg and pringle in muhammad (2008) to improve the theory with mention that performance not only affected by the capacity and willingness, but also by the opportunity afforded by a situation or environment with identifies factors chance as the missing dimension in the theory of performance. Thus, performance is a function of the interaction of a factor that is an opportunity, capacity and willingness (Karatepe et al., 2006; Sadikoglu and Zehir, 2010).

Gaspersz (2004) explained that the dimensions of the overall performance should be associated with the mission, goals, and objectives, relying on the ability to measure (measurability), valid and reliable, giving it a clear responsibility, attention to priorities and is useful for internal and external customers, stakeholders, and policy makers.

\section{Motivation}

McClelland in Robbins (2002) propose three main motives or the relevant needs of the workplace. The results of his research mentioned that there are three basic human needs that motivated;

1. Needs for achievement $(n A c h)$ : The drive to excellence, to achieve a series of standards to achieve success;

2. The need for power (nPow): the need to make people behave in ways that expected manner;

3. The need for afiliasi (nAff): affiliates (nAff): Craving closeness and friendship relationship interpersonal.

Improving performance employees within an organization can be done through the provision of motivation (Steers et al., 2004).

\section{Income/rewards}

The kinds of income to be received someone employees that is, (1). Financial reward, (2). Non financial reward that is salaries and/or wages, bonus, premium and others decent accepted by trade and accomplishment rise (Siagian, 1995). There are significant relation between extrinsic and intrinsic rewards and employee performance (Aktar et al., 2012)

\section{Education}

Davis \& Newstrom in Anwaruddin (2000) explains that the ability of employees consists of the ability of potential (intelegent quotient-IQ) and the ability of reality (knowledge skills) with the appropriate educational background with his post moves and skilled in their work on a daily basis easily reach the expected performance. The better and the right one's educational background and the better its performance (Bowman and Stephen, 1999)

\section{Age}

Waldman and Avolio in gomes (2003) explained that only a slight tendency that pass judgment low against the clerk who is older. These symptoms does not occur in a professional organizations. In environments that are full of rivalry, clashes between generations could affect the judgment and a perception of justice. $\mathrm{Ng}$ and Feldman (2008) explained that Education will be able to improve skills and expertise so that it can improve the performance of the organization

\section{Time of work}

Time of work an employee is an employee experience of the work since appointed officers with terms that have been defined and assigned duties in a State Office or other assignments as well as wages in accordance with the legislation in force until corresponding entered retirement. Martoyo in Subawa (2005) argues that the work experience or an employee is a person that is considered more capable in performing his duties, which will be awarded in addition to the intelegensinya capability as well as the basis for further considerations.

\section{Attitude}

Rosemberg in Gibson (1997) explained that people seek conformity between trust and feelings towards an object and suggested that a change in attitude hanging from one change (feeling) or of trust (beliefs) to be leveraging performance someone (Ostroff. 1992) 


\section{Work environment}

Hawthorne study conducted by Mayo in Ranupandojo (2002) concluded that there was great influence work environment on the performance of a clerk. The employee performance not only affected by the magnitude of wages or incentives of but also including work environment (Imran et al., 2012).

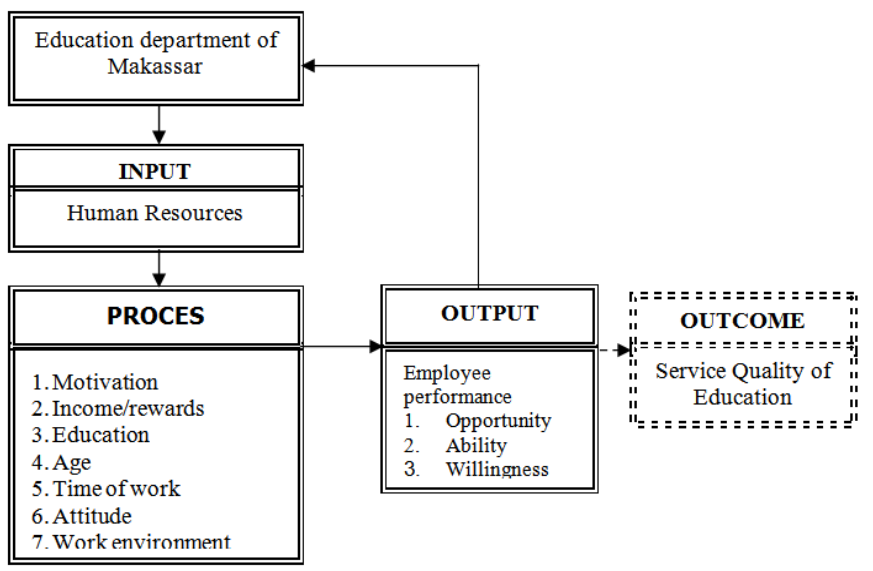

Figure 1: Theoritical framework

\section{Hypothesis}

Motivation, reward, education, age, time of work, attitude, work environment influence employee performance of Makassar education department

\subsection{Type and Location of research}

\section{Research methods}

This research is research explanatory that explain the link between the independent variable with the dependent variable. Data for analysis in research obtained from the education department Makassar through an interview with using questionnaries.

\subsection{Population and sample}

Population in this research is all civil servants on Makassar education department by 209 employees. As for the sheer size of the sample set with using formulas Slovin in Gani (2005) with a method of stratified random sampling

$$
\mathrm{n}=\frac{\mathrm{N}}{1+\mathrm{N}(\alpha)^{2}}
$$

Its proportions below;

\begin{tabular}{llllr}
$\begin{array}{l}\text { No } \\
\text { sample }\end{array}$ & \multicolumn{2}{c}{ Description } & \multicolumn{1}{c}{ number of employees } & Proportion of sample \\
1 & 0 & Eselon II & 1 & 0,30 \\
2 & 1 & Eselon III & 4 & 1,30 \\
3 & 7 & Eselon IIV & 21 & 6,83 \\
4 & 7 & Non Eselon & 183 & 59,54 \\
& 60 & Total & $\mathbf{2 0 9}$ &
\end{tabular}

\subsection{Technic analysis}

Technical analysis of data using in research;

1. Statistic descriptive

2. Inferential statistic;

$Y=\beta_{0}+\beta_{1} \mathbf{X}_{1}+\beta_{2} \mathbf{X}_{2}+\beta_{3} \mathbf{X}_{3}+\beta_{4} \mathbf{X}_{4}+\beta_{5} \mathbf{X}_{5}+\beta_{6} \mathbf{X}_{6}+\beta_{7} \mathbf{X}_{7}+\varepsilon$ 


\subsection{Description of employee performance}

\section{Discussion}

Table 1; Desription of variable

\begin{tabular}{|l|l|l|c|c|c|c|}
\hline \multicolumn{1}{|c|}{ Variable } & Mean & Score & Frequency & \% & Remark \\
\hline No & \multicolumn{1}{|c|}{ Description } & 46 & 67,65 & High \\
\hline 1 & Performance & 70,24 & $58-71$ & 43 & 63,24 & High \\
\hline 2 & Motivation & 53,13 & $44-55$ & 20 & 29,41 & Moderate \\
\hline 3 & Income & $2.622 .198,5$ & IDR2.500.100-2.725.000 & 33 & 48,53 & High \\
\hline 4 & Education & 16,47 & $16-17$ & 19 & 27,94 & High \\
\hline 5 & Age & 44,10 & $45-48$ & 25 & 36,76 & Moderate \\
\hline 6 & Time of work & 16,56 & $16-18$ & 48 & 70,59 & Positive \\
\hline 7 & Attitude & 59,35 & $49-60$ & 44 & 76,47 & High \\
\hline 6 & Work environmet & 73,97 & $61-75$ & & \\
\hline
\end{tabular}

\subsubsection{Employee performance}

The result of this research was mentioned that the employee performance is high on Makassar education and determined by its ability that is propelled by stronger capability that was on him and get a chance to fulfill his duties in the service of the public.

The results of observations indicated that procedures very easy to understand and easily carried out by employees of Makassar dept. of education so that people served with clear requirements already knew about technical and administrative services.

\subsubsection{Motivation}

The result of this research was mentioned that motivation work employees at Makassar dept. of education is high because its mean value the results of statistics 53,13 be in the value of 44 to score with a score of 55

The results of research concludes that motivation work employees at makassr dept. of education is high where its mean value found by 53,13 located in the score of 44 up to 55. It showed that motivation work employees to improve the performance of employees in carrying out a public service

\subsubsection{Rewards}

Employee income is obtained by mean value of IDR 2.600.000. Nevertheless, it is still the image of public servants who earn below IDR 2,000,000,- where the employee has a work period of about 10 years old or relatively new employees. Results of the study also showed that the income of employees in the Makassar Education dept. vary greatly in improving public services.

\subsubsection{Education}

The result of this research was mentioned that the length of completing education employees to the higher educational with its mean value by 16 years, and a frequency distribution of the most widely is undergraduate (S1). It showed that the level of education formal employees have a very good influence on improving performance

\subsubsection{Age}

This research found that the age of employees in general 49 - 51 years, namely $19,12 \%$ that was sitting on the average ( mean ) is 44,10, it show that the value of the attainment of those ages considered less good for melaksanaan routine tasks directly connected by a public service.

\subsubsection{Time of work}

The results of this study illustrate that enough employees working period with sufficient experience are able to improve their performance in carrying out its tasks and its responsibility for providing public services in the Makassar education dept. But the work is enough for an employee will not be able to prove his accomplishments if not given the opportunity to carry out the activities in the work programme of the unit it works.

\subsubsection{Attitude}

The results of this study found that the average value of employee attitudes are at 59,35 and employees attitudes who are positive on the range 49-60. This presupposes that the attitude of the employees of the Department of education of the city of Makassar may contribute to increased employee performance in order to carry out the best service to the community. 


\subsubsection{Work environment}

The results of this study found that the average value of employee attitudes and attitudes are at 59,35 employees who are positive on the range 49-60. This presupposes that the attitude of the employees of the Department of education of the city of Makassar may contribute to increased employee performance in order to carry out the best service to the community.

4.2 Correlation of motivation, income, age, time of work, attitude, and work environment through employee performance at Makassar education department

Correlation coefficient (R) on the model summary table of figures found 0,964 . This shows that there is a very strong relationship of work motivation, income, education, age, time of work, attitude of employees and the environment to employee performance on Makassar education department.

Tabel 2; Cofficient correlation (R) summary

\begin{tabular}{|c|c|c|c|}
\hline Notation & Multiple R & \multicolumn{2}{|c|}{ Remark } \\
\hline \multirow{5}{*}{$\mathrm{R}_{\mathrm{y}, \mathrm{x} 1, \mathrm{x} 2, \mathrm{x} 3, \mathrm{x} 4, \mathrm{x} 5, \mathrm{x} 6 \mathrm{x}, \mathrm{x} 7}$} & \multirow{5}{*}{0,964} & $0,80-1,000$ & $=$ Very strong \\
\hline & & $0,60-0,799$ & $=$ Strong \\
\hline & & $0,40-0,599$ & $=$ average \\
\hline & & $0,20-0,399$ & $=$ Low \\
\hline & & $0,00-0,199$ & $=$ Very low \\
\hline
\end{tabular}

Sources: Processed data. 2013

4.2.1 The effect of motivation, income, age, time of work, attitude, and work environment through employee performance at Makassar education department

Tabel 3; ANOVA(b)

\begin{tabular}{lllllll}
\hline & & & & & & \\
Model & & Sum of Squares & Df & Mean Square & F & Sig. \\
\hline 1 & Regression & 1936,743 & 7 & 276,678 & 114,100 & \\
& Residual & 145,493 & 60 & 2,425 & & \\
& Total & 2082,235 & 67 & & & \\
\hline
\end{tabular}

Sources: Processed data. 2013

The results of analysis from the above table shows that a significant value of 0,000 is smaller than 0,005 . Based on these two criteria it can be inferred that the free variables taken together affect the performance of employee performance of Makassar education dept. As for knowing the magnitude of the influence of independend variables with depedend variables, then the following regression correlation analysis results are presented in the following table in the model summary.

\begin{tabular}{cccc} 
& \multicolumn{3}{c}{ Tabel 4; Model Summary(b) } \\
\hline Model & $\mathrm{R}$ & R Square & Adjusted R Square \\
\hline & ,964(a) &, 930 &, 922 \\
\hline \multicolumn{2}{c}{ Sources: Processed data. 2013} &
\end{tabular}

Based on tables above seemed that adjusted $\mathrm{R}_{\mathrm{Square}}$ of 0,922 (coefficient of determination). This result indicates that ability variable motivation work (x1), variable income (x2), education variable (x3), variable age $(\mathrm{x} 4)$, variable working time (x5), variable attitude of employees (x6), and variable work environment (x7) explained variable the employee performance $(\mathrm{Y})$ by $92,20 \%$. The rest of $7,80 \%$ described by another variable not included in model this research as interest, gender, rank and category, discipline of work, job training, and others

Tabel 5; Coefficients(a)

\begin{tabular}{|c|c|c|c|c|c|c|}
\hline \multirow[t]{2}{*}{ Model } & & \multicolumn{2}{|c|}{$\begin{array}{c}\text { Unstandardized } \\
\text { Coefficients }\end{array}$} & \multirow{2}{*}{$\begin{array}{c}\begin{array}{c}\text { Standardized } \\
\text { Coefficients }\end{array} \\
\text { Beta } \\
\end{array}$} & \multirow{2}{*}{$\begin{array}{l}\mathbf{T} \\
\mathbf{B}\end{array}$} & \multirow[t]{2}{*}{ Sig. } \\
\hline & & B & Std. & & & \\
\hline \multirow[t]{8}{*}{1} & (Constant) & 17,725 & 3,736 & & 4,745 &, 000 \\
\hline & Motivation &, 359 &, 065 & ,315 & 5,535 &, 000 \\
\hline & Income & 1,132 & ,414 & , 137 & 2,731 & ,008 \\
\hline & Education &, 301 & 149 &, 113 & 2,028 &, 047 \\
\hline & Age &,- 184 & ,085 &,- 135 & $-2,178$ & 033 \\
\hline & Time of work & ,287 & ,104 &, 183 & 2,763 & ,008 \\
\hline & Attitude & 242 & ,073 & ,245 & 3,293 & ,002 \\
\hline & Work environment & 247 & ,066 & 258 & 3,749 &, 000 \\
\hline
\end{tabular}

Sources: Processed data. 2013 


\section{The effect of motivation on employee performance}

Based on the analysis also found that the coefissien coefficient of regression is 0,315 . This means that employees work motivation variables (X1) contributed a real 0,315. Any improvement work motivating employee performance will increase by $32 \%$. If seen as a whole independend variables studied, motivation variable thus greatest employees contribute to affect the performance of an Makassar employee of education department.

\section{The effect of income on employee performance}

Based on the result analysis found that regression coefficient of 0,137. It means that employees income (x2) leveraging performance by 0,137 . That means any income increased employee will increase performance by employees of $14 \%$. Considered as a whole variable, variable income is fifth major after motivation employees work contributing to affect employees performance education dept. the city of Makassar

\section{The effect of education on employee performance}

Based on the result of analysis found that regression coefficient of 0,113 which means income employees ( $x 3$ ) influences the performance of 0,113 . This means that every education improvement of employees will be improving the performance of employees from $11 \%$. If viewed as a whole independend variable and education variable sixth major in contributes to improving the performance of employees at Makassar dept. of education

\section{The effect of age on employee performance}

Based on analysis conducted found that regression coefficient of the effect of age on employee performance is $-0,135$. It means that the age of employees $(x 4)$ influences the performance is about $-0,135$. The interesting thing of the regression coefficient this is that every increase in the age of employees approaching retirement age and it would lower the employee performance as much as by $14 \%$. If viewed as a whole and free to be researched variable variable whose age is in the seventh position in influencing the employee performance on education for the city of Makassar

\section{The effect of time of work on employee performance}

Based on the results of the regression analysis found that coefficient's of the influence of time of work on performance is 0,183 . This means that the employee's work period (X 5) affect the performance of $18 \%$. If seen as a whole, it appears that time of work are at the fourth stage in contributing to affect the performance of an employee on duty education city of Makassar

\section{The effect of attitude on employee performance}

Based on the result analysis of the coefficients against the influence of attitude toward the performance of obtained regression coefficient of 0,245 which means that variable attitude employees (x6) to exert an influence real worth 0,245 . It means that every increase in motivation of the verb be improving the performance of employees by $25 \%$. If viewed as a whole, so it can be said that a variable attitude employees are variable most second big who contributes to improving the performance of employees at education for the city of Makassar

\section{The effect of work environment on employee performance}

Based on the results of the analysis of the influence of work environment on performance obtained regression coefficient of 0,254 . This means that the employee work environment variables (X 7) gives the real influence of 0,254 . The regression coefficient means that any improvements in workplace conditions will improve the performance of employees by $25 \%$. If seen as a whole free variables examined employee work environment variables so that both contribute to affect the performance of an employee at the Education Office in the city of Makassar.

\subsection{Conclusions}

\section{Conclusion, Suggestion and Limitation}

1. The high performance employees at Makassar dept. of education in giving the public services, due to the encouragement motivation work tinggi, an income adequate, formal education, high after the civil servants who established, working time enough, a positive attitude employees and work environment conducive as well as civil servants who are comfortable in carrying out a public service

2. There is a very strong relationship between the motivation, income, employee's age, duration of employees work, employee attitudes, and work environment with employees performance on Makassar Education Department. 


\subsection{Suggestion}

1. Significant influence between the motivation of work, income, education, age, time of work, attitude of employees, and the environment to employee performance on Makassar education department. Then presumably it is no exaggeration if the variables need scrutiny and become the focus of attention in the efforts for human resource development that is higher quality.

2. Removal of employees to a certain tenure should age limit is at least 40 and also age 51 up approaching retirement not provide burden routine tasks directly connected with the duty of the public service.

3. Training employees need to have regard or giving a push motivation work employees employees, raising income fix or adjust the education level of employees presented awards based on age and working time, as well as improving environmental conditions of employment.

\subsection{Limitation}

Variables this research is motivation, income education, age, working time, the attitude of employees work environment, and performance of Makassar education department employee. By because it was necessary to analyze reëxamined model the regression equation is variable research, by taking into account development regions samples plus the analysis sharper for the development of human resources

\section{References}

[1] Keban. 2004. Enam Dimensi Strategis Administrasi Publik. Cetakan Pertama. Gava Media. Yogyakarta.

[2] Vroom. 1964. Work and motivation. San Francisco, CA: Jossey-Bass.

[3] Muhammad, Fadel dan Toruan, Rayendra L. 2008. Reinventing local government: Pengalaman dari daerah. Penerbit Elex Media Komputindo

[4] Karatepe, O.M., O. Uludag, I. Menevis, L. Hadzimehmedagic and C.L. Baddar, 2006. The effects of selected individual characteristics on frontline employee performance and job satisfaction. Tourism Management, 27: 547-560.

[5] Sadikoglu, E. and C. Zehir, 2010. Investigating the effects of innovation and employee performance on the relationship between total quality management practices and firm performance: An empirical study of Turkish firms. International Journal Production Economics, 127: 13-26.

[6] Gaspersz, Vincent. 2004. Production Planning and Inventory Control. PT Gramedia Pustaka Umum. Jakarta

[7] Robbins. P.S.,2002, Prinsip-prinsip Perlaku Organisasi. Edisi kelima. Penerbit Erlangga, Jakarta.

[8] Steers, R.M., Mowday, R.T.\& Shapiro, D.L. 2004. The future of work motivation Theory. Academy of Management Review, Vol.29, No.3 pp.379-387.

[9] Siagian, Sondang, P. 2003. Manajemen Sumber Daya Manusia. Jakarta: Bumi Aksara.

[10] Aktar, Serena, Kamruzzaman, Muhammad Sachu, and Ali, Md. Emran. 2012. The Impact of Rewards on Employee Performance in Commercial Banks of Bangladesh: An Empirical Study. IOSR Journal of Business and Management (IOSR-JBM). Volume 6, Issue 2 (Nov. - Dec. 2012), p.09-15

[11] Anwaruddin, Awang. 2006. Pemberdayaan Pelayanan Publik. Jurnal Ilmu Administrasi. Volume 3/No. 3 2006

[12] Bowman, William R. and Mehay, Stephen L. 1999. Graduate education and employee performance: evidence from military personnel. Economics of Education Review 18 (1999) 453-463

[13] Gomes, Faustino Cardoso. 2003. Manajemen Sumber Daya Manusia. Penerbit Andi. Yogyakarta.

[14] Ng, T. W. H., and Feldman, D. C. 2008. The relationship of age to ten dimensions of job performance. Journal of Applied Psychology, 93, 392-423.

[15] Subawa, I Made. 2005. Pengaruh Penempatan, Lingkungan Kerja, Pengawasan Atasan Langsung dan Balas Jasa terhadap Disiplin Pegawai pada Sekretariat Daerah Kabupaten Badung, Tesis, Program Magister Managemen Universitas Udayana

[16] Gibson, James .L. 1997. Manajemen. Alih bahasa Zuhad Ichyandin. Edisi 9. Jakarta. Erlangga.

[17] Ostroff, C. 1992. The Relationship Between Satisfaction, Attitudes, and Performance: An Organizational Level Analysis. Journal of Applied Psychology. Volume 77, No. 6, 963-974.

[18] Ranupandojo, Heidjrachman dan Husnan. 2002. Manajemen Personalia. Cetakan kedua. Yogyakarta. BPFE.

[19] Imran, Rabia, Afsheen Fatima, Arshad Zaheer, Imran Yousaf and Iram Batool. 2012. How to Boost Employee Performance: Investigating the Influence of Transformational Leadership and Work Environment in a Pakistani Perspective. Middle-East Journal of Scientific Research 11 (10): 1455-1462

[20] Azwar, Saifuddin, 1989. Sikap Manusia; Teori dan Pengukurannnya. Yogyakarta. Liberty.

[21] Atmosidrjo, Prajudi. 2003. Teori Admnistrasi. Jakarta. STIA-LAN.

[22] Burhanuddin, A. 2001. Review Tentang Penilaian Pelaksanaan Pekerjaan dan Strategi Penetapan Standar Penilaian Kinerja Pegawai Negeri Sipil. Jurnal Ilmu Administrasi. Volume 7 No. 4

[23] Dwiyanto, Agus (edit). 2005. Mewujudkan Good Governance Melalui Pelayanan Publik. Jogjakarta: Gadjah Mada University Press.

[24] Nawawi, Juanda. 2004. Analisis Desentralisasi dan Kinerja Pelayanan Publik Di Kabupaten Wajo. Disertasi. Universitas Hasanuddin.

[25] Peraturan Pemerintah Nomor 10 Tahun 1979 tentang Penilaian Pelaksanaan Pekerjaan Pegawai Negeri Sipil tanggal 15 Mei 1979

[26] Sinambela, Lilian Poltak dkk. 2007. REFORMASI PELAYANAN PUBLIK; Teori, Kebijakan dan Implementasi. Jakarta: Bumi Aksara.

[27] Surat Edaran Kepala Badan Administrasi Kepegawaian Nomor 02/SE/1980 tentang Penilaian Pelaksanaan Pekerjaan Pegawai Negeri Sipil tanggal 11 Pebruari 1980.

[28] Undang-Undang Republik Indonesia No. 43 Th. 1999 tentang Perubahan UU No. 8 Tahun 1974 tentang Pokok-Pokok Kepegawaian. 2000. PT. Sinar Grafika Offset. Jakarta.

[29] Wahidin. 2006. Perilaku Birokrasi Dalam Pelayanan Publik. Jurnal Administrasi Negara. Volume 12 No. 4 Desember 2006 